\title{
Consistency and mechanical properties of sustainable concrete blended with brick dust waste cementitious materials
}

\author{
S. Y. Amakye ${ }^{1} \cdot$ S. J. Abbey ${ }^{1} \cdot$ A. O. Olubanwo ${ }^{2}$
}

Received: 3 August 2020 / Accepted: 24 February 2021 / Published online: 4 March 2021

(C) The Author(s) 2021 OPEN

\begin{abstract}
The reuse of waste materials in civil engineering projects has become the topic for many researchers due to their economic and environmental benefits. In this study, brick dust waste (BDW) derived from cutting of masonry bricks and demolition waste which are normally dumped as land fill is used as partial replacement of cement in a concrete mix at $10 \%, 20 \%$ and $30 \%$ respectively, with the aim of achieving high strength in concrete using less cement due to the environmental problems associated with the cement production. To ascertain the effects of BDW on the consistency and mechanical performance of concrete mix, laboratory investigations on the workability of fresh concrete and the strength of hardened concrete were carried out. Slump and compaction index test were carried out on fresh concrete mix and unconfined compressive strength (UCS) test and tensile strength test were conducted on hardened concrete specimen after 7, 14 and 28 days of curing. The results showed high UCS and tensile strength with the addition of $10 \%$ BDW to the concrete mix, hence achieving the set target in accordance with the relevant British standards. A gradual reduction in strength was observed as BDW content increases, however, recording good workability as slump and compaction index results fell within the set target range in accordance with relevant British standards. Findings from this study concluded that BDW can partially replace cement in a concrete mix to up to $30 \%$ igniting the path to a cleaner production of novel concrete using BDW in construction work.
\end{abstract}

Keywords Brick dust waste · Partial cement replacement - Construction demolition waste - Unconfined compressive strength · Tensile splitting strength · Workability · Green concrete

\section{Introduction}

Recent growth in the world's population has triggered an increase in the demand for concrete products for the construction of more building for use as homes and other infrastructure. This has led to the consumption of billions of tons of our natural resources such as clinker, water and aggregates by construction industries to produce cement; therefore, increasing the problems associated with cement production such as high greenhouse gas (GHG) emission and environmental pollution [1].
Cement consumption in 2014 in developed economies increased by about 9.2 million metric tons followed by 9 million metric tons in 2015 and is expected to grow from $2.3 \%$ in 2019 and $1.7 \%$ in 2020 [2]. The world cement vision predicted a rise in GHG emission in 2020 due to a rise in demand for cement worldwide [3]. According to [4] approximately one ton of $\mathrm{CO}_{2}$ is produced in preparation of one ton of cement. The negative impact of cement production has raised concerns to push towards a more sustainable practice of using recycled waste materials. By-products pozzolanic materials such

$\triangle$ S. Y. Amakye, Samuel.amakye@uwe.ac.uk; S. J. Abbey, Samuel.abbey@uwe.ac.uk; A. O. Olubanwo, aa7878@coventry.ac.uk| ${ }^{1}$ Civil Engineering Cluster, Department of Geography and Environmental Management, Faculty of Environment and Technology, University of the West of England, Bristol, UK. ${ }^{2}$ Shool of Energy, Construction and Environment, Faculty of Engineering, Environment and Computing, Coventry University, Coventry, UK. 
as marble dust has been used in concrete production [5]. Quarry dust, fly ash and billet scale are successfully used in a study as cement replacement in a concrete mix [6]. Cementitious materials such as fly ash, rice hush ground granulated blast furnace slag, and bagasse ash can be used in concrete mix due to their pozzolanic properties [7]. Clay bricks ground to cement fineness was partially replaced with cement at $0 \% 10 \%, 20 \%$ and $30 \%$ in standard mortar [8].

About $14 \%$ of construction and demolition waste is made up of bricks and reasonable results have been achieved when Brick dust waste (BDW) was used as a substitute for cement at 5\%,10\% and 15\% [9].

Brick dust waste is a pozzolanic material when mixed with cement produces calcium silicate hydrate gel (C-S-H) which determines the strength of concrete. Any materials with a siliceous and aluminous content that reacts with calcium hydroxide when in contact with water to form cementitious hydration product are referred to as Pozzolans [10]. Ancient structures in Rome and Egypt used pozzolans as part of the cement used in their construction [11]. Excessive dumping of construction and demolition waste as landfill has influenced current research to consider the use of construction and demolition waste as partial replacement for cement due to the negative environmental impact associated with landfill. Using waste materials in the construction sector will reduce the overall cost of construction and the negative environmental effects associated with cement production leading to a more sustainable construction industry. Bricks are manufactured by the calcination of alumina-silicate clay and ground to suitable fineness to possess pozzolanic properties and made brittle by subjecting it to a high temperature of about 1000 to $1100{ }^{\circ} \mathrm{C}$ and the creation of a liquid glassy phase when cooling indicate high pozzolanic properties [8]. Although kaolinite loses its structural water around $600{ }^{\circ} \mathrm{C}$ to form metakaolin, this new material is used as pozzolan in finely divided form in cement-based system [12]. In this study, detailed investigation into the consistency and mechanical properties of concrete made from partially replaced cement with brick dust waste at varying proportions is presented, and it highlights the tests conducted along with the appropriate standards adopted. The study will outline the experimental methods used, describing the samples preparation, design mix and various tests conducted on fresh and hardened concrete. Results and discussion section will focus on presenting and discussing the results obtained from the various tests conducted, which subsequently provides the key findings given in the conclusions and recommendations for future work.

\section{Scope of the study}

This study will contribute to the understanding of partially replacing cement with BDW focusing on the workability of fresh concrete and the strength of hardened concrete. Slump and compaction index test were carried out on wet concrete and unconfined compressive test and tensile splitting test were conducted on hardened concrete. The study focuses on the replacement of cement with brick dust waste and its effect on strength and workability. CEM II cement was used and a strength class of RC 35/45 was adopted. A target Class S3 was set for the slump test as recommended by BS EN 206:2013 + A1:2016(E) which suggest a slump range of 100 to $150 \mathrm{~mm}$. A target Class C3 was set for compaction index test as recommended by $B S$ EN 206:2013 + A1:2016(E) which suggest a degree of compatibility range of 1.10 to 1.04 in accordance with BS 85002-2015 + A1:2016. Unconfined compressive strength test was conducted in line with BS EN 12390-3:2019 and ASTM C109/C109M-20b after the samples were cured in water for 7,14 and 28 days. A tensile splitting test was conducted after 28 days of curing the samples in water in accordance with BS EN 12390-6-2009 and ASTM C496/C496M-17. The results from the tests will be compared with the target values provided by British Standards (BS) and the American Society for Testing and Materials (ASTM).

\section{Materials and method}

The materials used in this study include brick dust waste, Portland cement, limestone aggregate (coarse) $10 \mathrm{~mm}$ (10/4) and $20 \mathrm{~mm}(20 / 10)$ grade, natural sea-dredged sand (fine aggregate). Brick dust used in the study is a waste from cutting of fired bricks supplied by Brick Fabrication Ltd, Gemini works, Pontypool, South Wales, UK. Portland cement type BS EN 197-1 CEM II/B-V 32.5R with a minimum compressive strength of $32.5 \mathrm{~N} / \mathrm{mm}^{2}$ was used in accordance with BS EN 197-1:2011a and supplied by Lafarge Cement UK through a local contractor. Fine and coarse aggregate used in the study was supplied by a local contractor in line with PD 6682-1-:2009. Sieve analysis was conducted by the local supplier in accordance with BS EN 12620:2002+A1:2008 and BS EN 9331:2012. Consistency limit and particle size distribution of brick dust waste (BDW) are shown in Table 1 and Fig. 1, Chemical composition mineralogy and physical properties of BDW and PC are shown in Table 2 and Particle size distribution (Figs. 2, 3, 4), chemical composition and other properties of sand and stone are shown in Table 3. 
Table 1 Consistency limit and particle size distribution of BDW

\begin{tabular}{lc}
\hline Consistency limits BDW & Description \\
\hline Liquid limit $\mathrm{w}_{\mathrm{L}}(\%)$ & - \\
Plastic limit $\mathrm{w}_{\mathrm{P}}(\%)$ & - \\
Plasticity index $\mathrm{I}_{\mathrm{P}}(\%)$ & Non-plastic \\
\hline Others & Value \\
\hline Specific gravity & 2.5 \\
Bulk density $\left(\mathrm{kg} / \mathrm{m}^{3}\right)$ & 1837 \\
Maximum dry density $\left.(\mathrm{MDD}) \mathrm{Mg} / \mathrm{m}^{3}\right)$ & 1.5 \\
Optimum moisture content $(\mathrm{OMC})(\%)$ & 17 \\
Blaine fineness $\left(\mathrm{m}^{3} / \mathrm{kg}\right)$ & 369 \\
Colour & Brick red \\
\hline
\end{tabular}

Fig. 1 Particle size distribution of aggregates and brick dust waste used

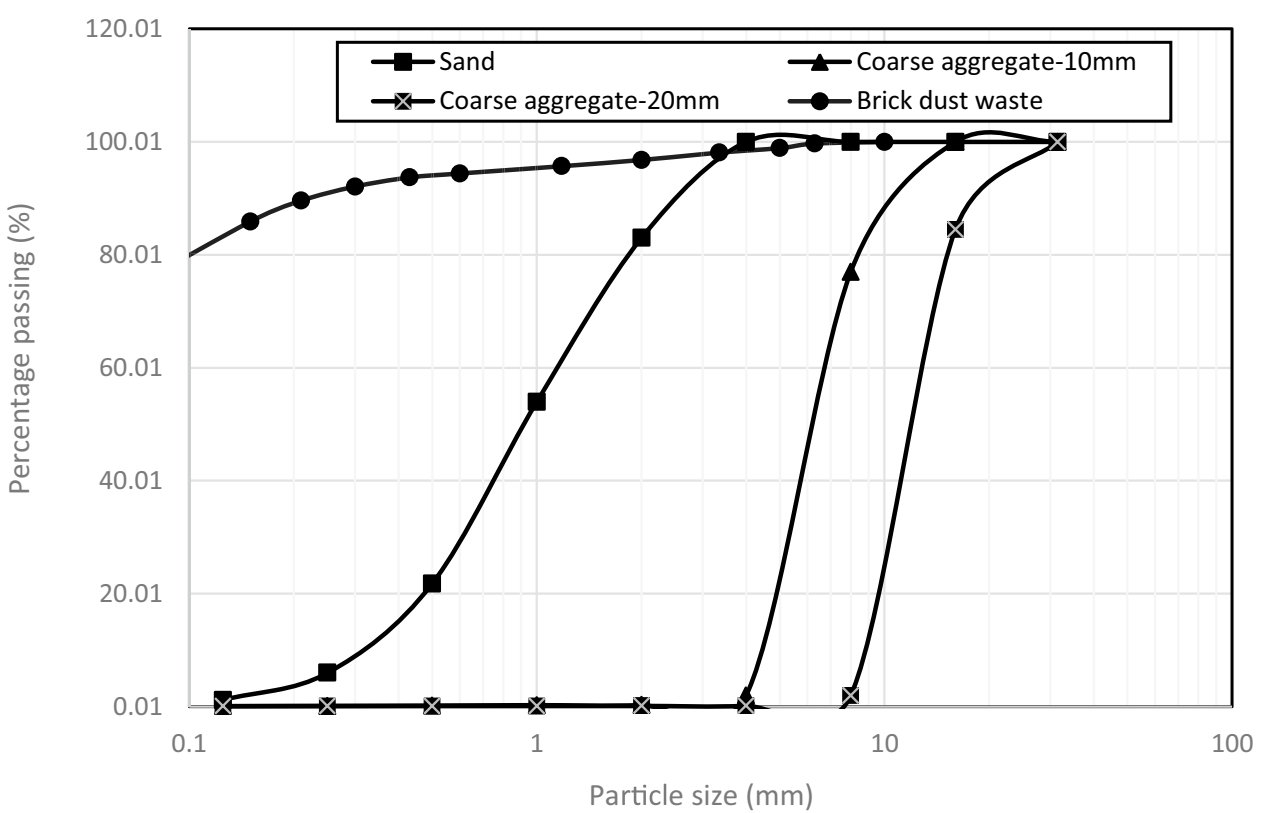

\subsection{Experimental Method}

\subsubsection{Mix design and sample preparation}

Based on BS 8500-2:2015+A1-2016, concrete type RC35/45 was adopted and four batches of concrete mix were prepared with ratio 1:2:3 and water-cement ratio $(\mathrm{w} / \mathrm{c})$ 0.5, cement was partially replaced with BDW based in the control mix. Nine (9) cubes (100 mm $\times 100 \mathrm{~mm} \times 100 \mathrm{~mm}$ ) and two (2) cylindrical specimens $(100 \mathrm{~mm}$ diameter and $200 \mathrm{~mm}$ height) were made per mix. Based on the design criteria for control mix in Table 4, Mix composition (MC)1-3 were designed by replacing cement with BDW at 10\%, 20\% and $30 \%$ by weight of various materials.

Based on the mix design, dry materials were mixed using a concrete mixer and a measured amount of water added. An oiled steel cube and cylindrical moulds filled with fresh concrete and vibrated for up to $40 \mathrm{~Hz}$ for $5 \mathrm{~s}$ using a vibrating table until no further settlement was observed, and a compact and air free concrete achieved. The surface was levelled and store without any seal in a room for $24 \mathrm{~h}$ with a temperature of about $20 \pm 5^{\circ} \mathrm{C}$. With the help of a powered tool, the dry concrete samples were de-moulded and cured in water to be tested after 7,14 and 28 days.

\subsubsection{Fresh concrete testing}

3.1.2.1 Slump test Slump test was carried out for all mix compositions in line with BS EN 12,350-2:2009. During the test, a metal cone mould with height $300 \mathrm{~mm}$, base diameter $200 \mathrm{~mm}$ and top diameter $100 \mathrm{~mm}$ with two handles 


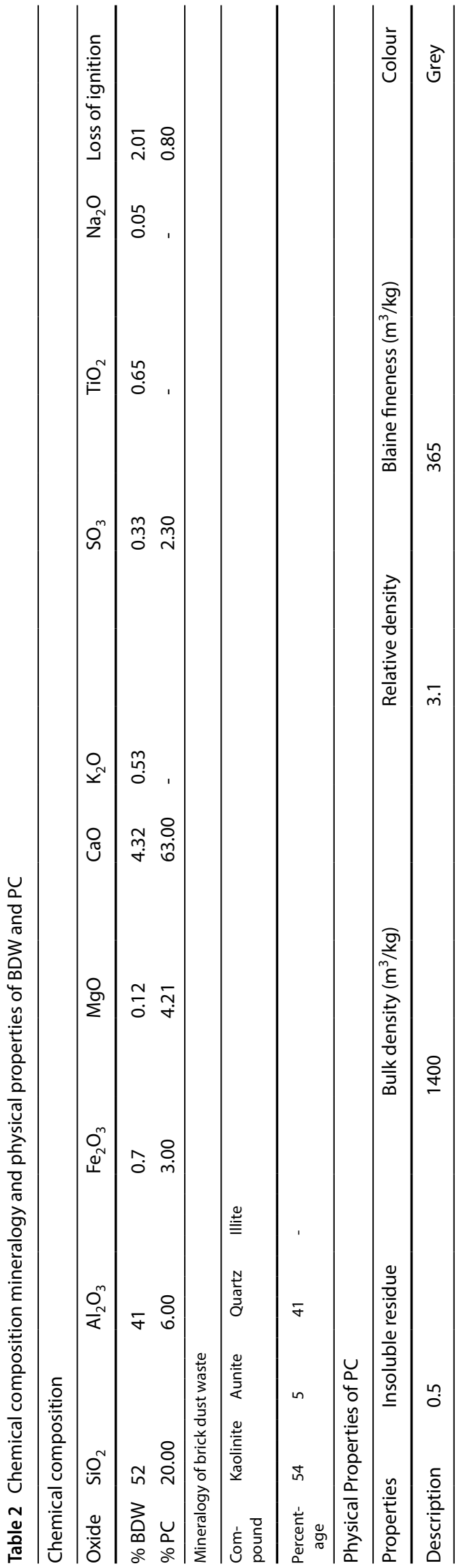

and two fool rest were used. The cone was placed on a non-absorbent surface with the top diameter $100 \mathrm{~mm}$ facing up. With a firm grip of the handle and footrest, the mould was filled with fresh concrete in three layers. Each layer of concrete was tapped 25 times with a standard steel rod (16 mm diameter and $600 \mathrm{~mm}$ length). The rod was rolled horizontally over the top of the mould to level the concrete. The mould was lifted slowly using the handle leaving unsupported concrete to slump. The metal cone is placed next to the slumped concrete and the $600 \mathrm{~mm}$ long rod was placed on top of the empty cone mould to set as a target. The distance between the set target and the slumped concrete was measured using a measuring ruler. The value of the measurement is the slump value of fresh concrete. Figs. 5 and 6 show the slump test and the types of slump.

3.1.2.2 Compaction index (Cl) test Compaction index was carried out to determine the degree of compaction of fresh concrete. This test was carried out for all mix compositions in accordance with BS 12350-4:2009. A measuring ruler, hand trowel, vibrating table, $600 \mathrm{~mm}$ long steel rod and a rectangular metal container with internal dimensions $400 \mathrm{~mm}$ height and $200 \mathrm{~mm}$ base were used in this test. With the help of a hand trowel, the rectangular container was filled with fresh concrete to the top and levelled by rolling a $600 \mathrm{~mm}$ steel rod over the top of the mould. The mould with concrete was then vibrated for up to $40 \mathrm{~Hz}$ using a vibrating table until no further settlement was observed. The distance (S) from the surface of the compacted fresh concrete to the top edge of the metal mould was measured with a measuring ruler and the values recorded. Compaction index was determined using Eq. 1. Compaction index test process is shown in Figs. 7, 8 and 9.

$\mathrm{Cl}=\frac{H}{H-S}$

where, $\mathrm{H}=$ Internal height of the container and $\mathrm{S}=$ Mean value of 'S'.

\subsubsection{Hardened concrete testing}

3.1.3.1 Unconfined compressive strength (UCS) Hardened concrete cube was tested for compressive strength after 7,14 and 28 days of curing in line with BS EN 12,3903:2019 and ASTM C109/C109M-20b. Using compressive test equipment, a vertical force was applied to cube specimen at a rate of $6 \mathrm{kN} / \mathrm{sec}$ until failure and the failure load was recorded. Base on recorded failure loads for various mix composition, unconfined compressive strength was determined using Eq. 2. 


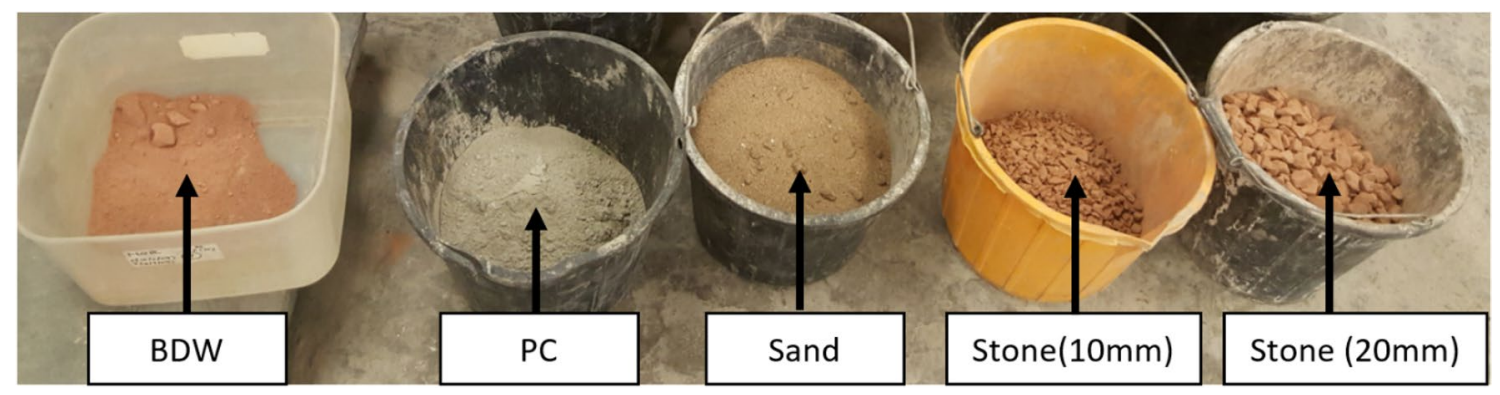

Fig. 2 Materials used in the study

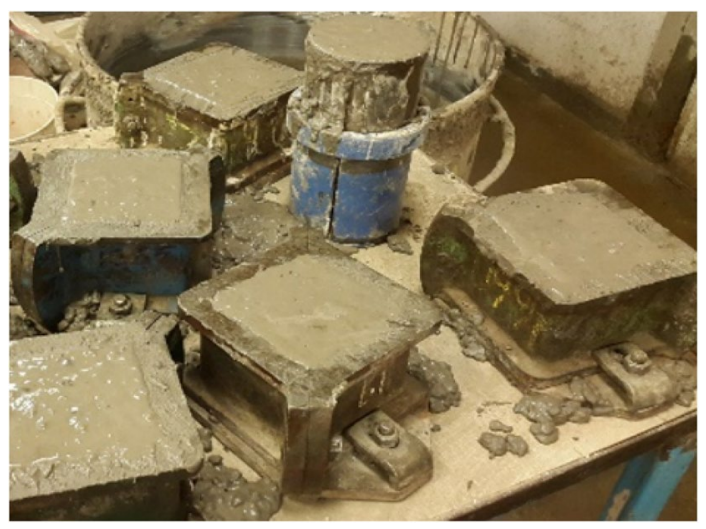

C496M-17. The cylinder specimen was put into a steel frame and places horizontally between the platens of a compressive test machine. A constant vertical force was applied along the length of the specimen at a stress rate of $1.57 \mathrm{kN} / \mathrm{sec}$ until failure and the failure load was recorded as shown in Figs. 10, 11 and 12. Tensile splitting strength was determined using Eq. 3.

$\mathrm{TSS}(\mathrm{N} / \mathrm{mm})=\frac{2 F}{\pi L d}$

where, $\mathrm{F}=$ Maximum load at failure $(\mathrm{N}), \mathrm{L}=$ length of specimen $(\mathrm{mm}), \mathrm{d}=$ diameter of specimen $(\mathrm{mm})$.

Fig. 3 Fresh concrete in a steel mould

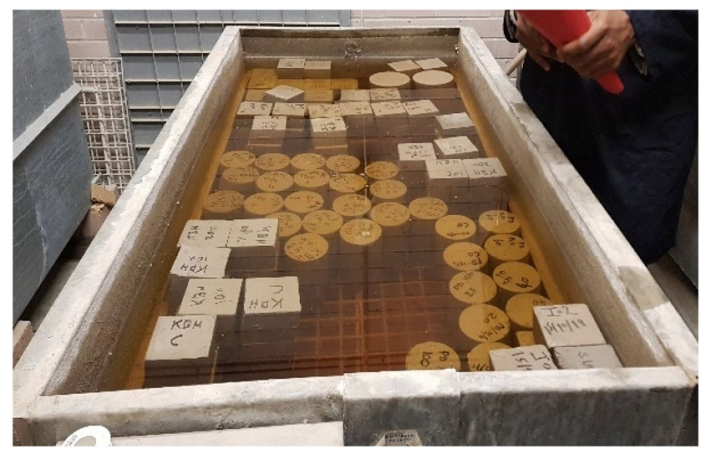

\section{Results and discussion}

The results obtained from the laboratory test conducted on the consistency and mechanical properties of concrete composed of varying brick dust waste proportions show good consistency and workability for fresh concrete and improved strength for hardened concrete. A true slump and good compaction index values were achieved. However, low slump was recorded for mix composition MC2 composed of $20 \%$ BDW and MC3 composed of $30 \%$ BDW and low compaction index value recorded for MC 3 composed of $30 \%$ BDW. A gradual reduction in slump and compaction index was observed with an increase in brick duct waste content. High compressive and tensile strengths were achieved for all mix compositions which signify strength improvement with the addition of brick dust waste as partial replacement for cement. Compared to the control mix, no significant difference in splitting tensile strength was achieved indicating good performance. The overall results obtained from this experiment prove that brick dust waste has the ability to improve the strength and consistency of concrete. 


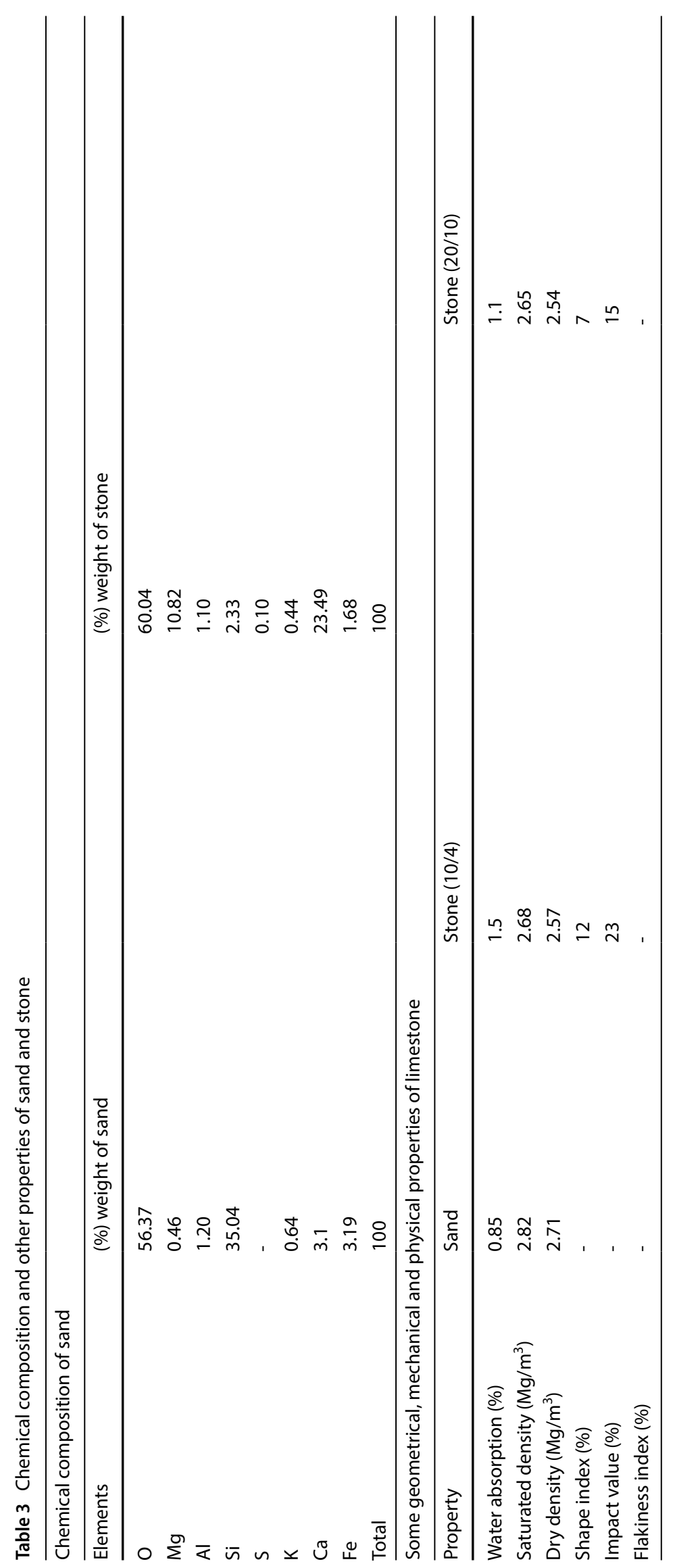


Table 4 Mix proportions and material

\begin{tabular}{|c|c|c|c|c|c|c|c|}
\hline \multirow[t]{3}{*}{ Mix Composition } & \multirow{3}{*}{$\begin{array}{l}\text { Replacement } \\
\text { (\%) }\end{array}$} & \multirow{3}{*}{$\begin{array}{l}\mathrm{PC} \\
\mathrm{kg}\end{array}$} & \multirow{3}{*}{$\begin{array}{l}\text { BDW } \\
\mathrm{kg}\end{array}$} & \multirow{3}{*}{$\begin{array}{l}\text { Sand } \\
\mathrm{kg}\end{array}$} & \multicolumn{3}{|c|}{ Limestone } \\
\hline & & & & & $10 \mathrm{~mm}$ & $20 \mathrm{~mm}$ & water \\
\hline & & & & & $\mathrm{kg}$ & $\mathrm{kg}$ & litres \\
\hline Control Mix & 0 & 5 & 0 & 10 & 6 & 9 & 3 \\
\hline MC 1 & 10 & 4.4 & 0.5 & 10 & 6 & 9 & 3 \\
\hline MC 2 & 20 & 3.9 & 1 & 10 & 6 & 9 & 3 \\
\hline MC 3 & 30 & 3.5 & 1.5 & 10 & 6 & 9 & 3 \\
\hline
\end{tabular}

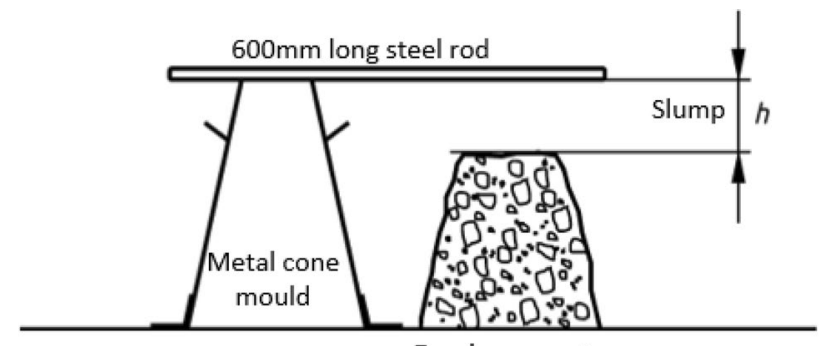

Fresh concrete

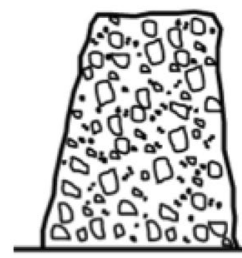

True slump

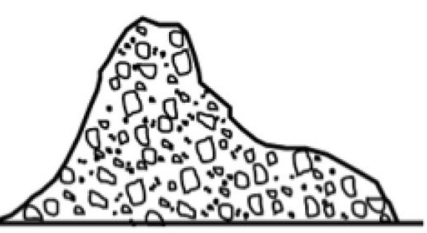

Shear slump

Fig. 5 Slump test and types of slumps (British Standard)

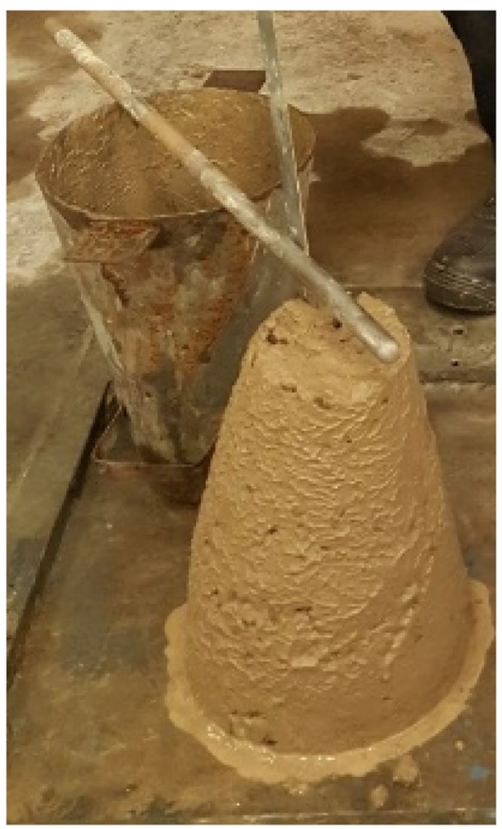

Fig. 6 Laboratory slump test

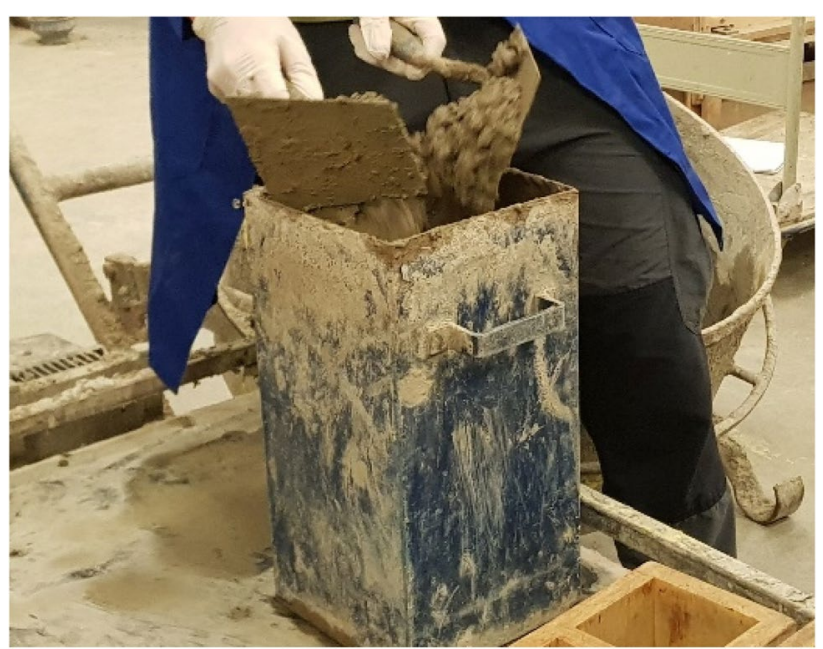

Fig. 7 Filling mould with fresh concrete

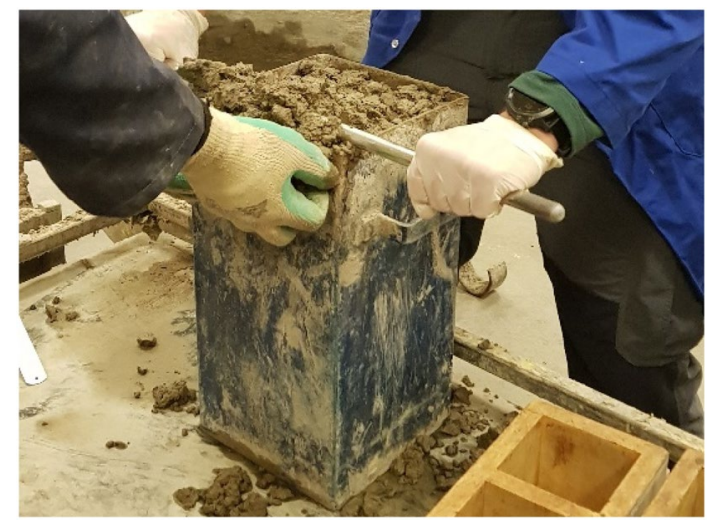

Fig. 8 Levelling the top of the mould

\subsection{Fresh concrete}

\subsubsection{Slump and Compaction Index}

A variation in slump was observed for each mix composition and a drastic reduction in slump of $110 \mathrm{~mm}$ (MC 1) to $40 \mathrm{~mm}$ (MC 2) was observed. However, a true slump was 


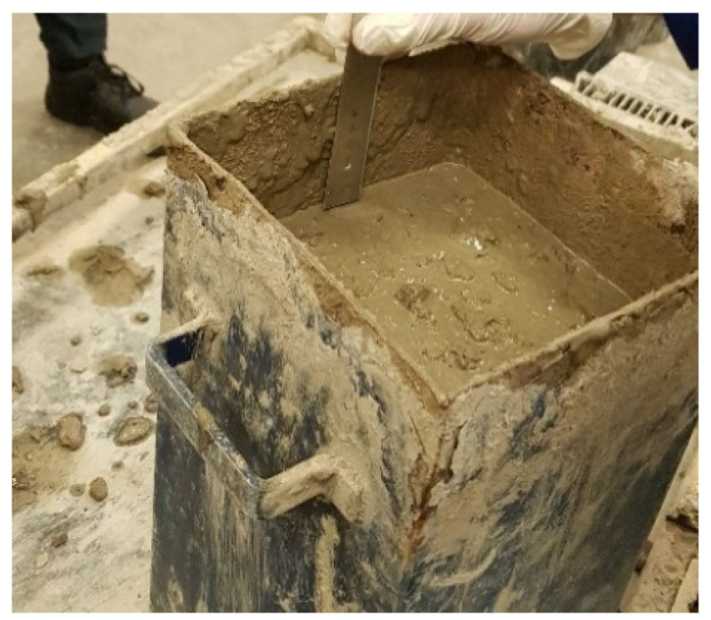

Fig. 9 Measuring distance (s)

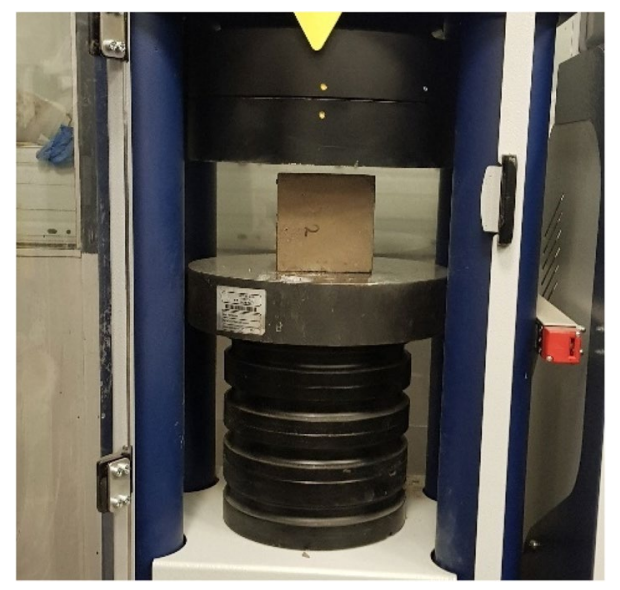

Fig. 10 Applying vertical force to cube specimen

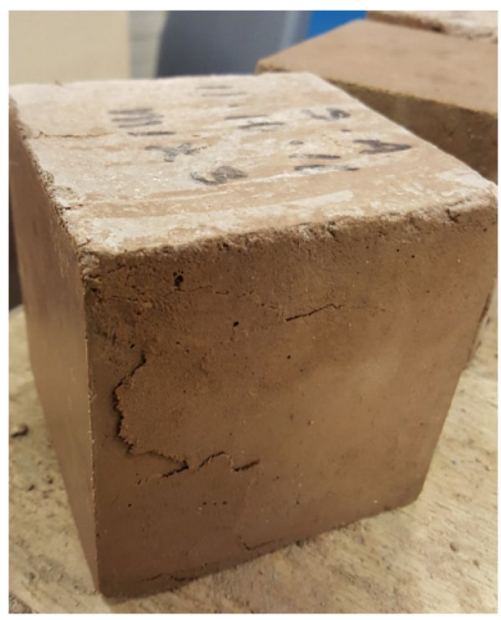

Fig. 11 Failed cube specimen with cracks

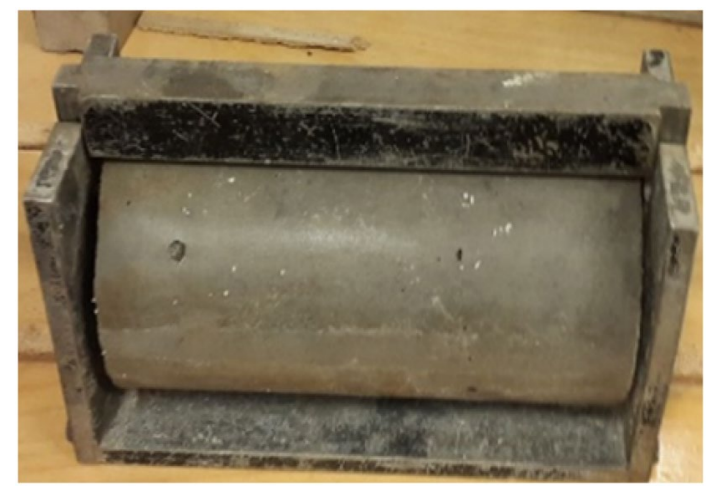

Fig. 12 Cylindrical specimen locked in steel frame

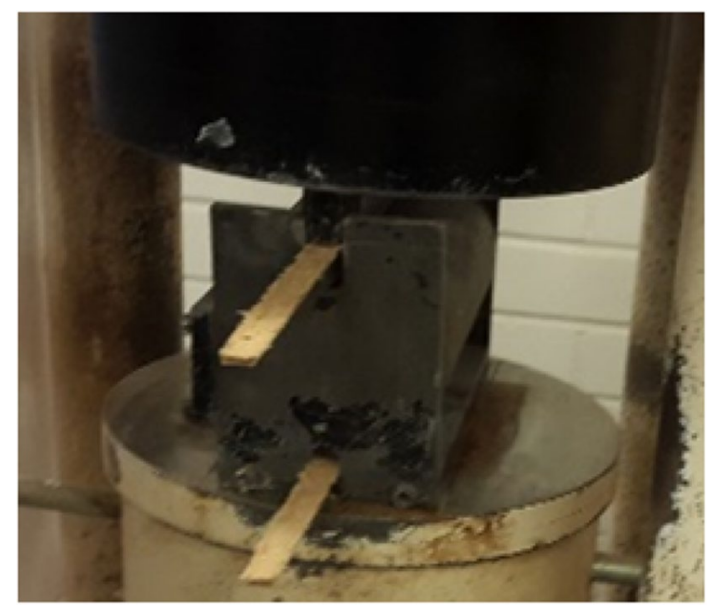

Fig. 13 Applying vertical force on the cylindrical test specimen

achieved with MC 1 comprising of $10 \%$ BDW as shown in Fig. 13 in accordance with BS EN 12350-2:2009. The results show that MC 2 and MC 3 did not achieved the set target range, however, they can still be used in construction work. All mix compositions fell within the set target range for compaction index in line with BS 12350-4:2009. However, a gradual reduction in compaction index was observed as BDW content increases. Variations in slump value of the concrete mix are as a result of the physical properties of BDW influencing the consistency of fresh concrete with varying brick dust content [13]. In a similar study where BDW was added to a concrete mix at $10 \%, 20 \%$ and $30 \%$, similar trend of results were observed by [9]. The study indicates that every percentage increase in ground clay bricks results in a gradual reduction in slump value [12]. However, the reduction in slump cannot be attributed to the increase in BDW content alone, changes in watercement ratio $(\mathrm{w} / \mathrm{c})$ and rate of water absorption by BDW in different mix compositions also play a major role. A study conducted by [8] revealed that $25 \%$ of PC replacement by 
ground brick in the concrete mix had no significant effect on water demand. An increase in absorption properties of concrete increased with an increased coconut shell content. In [14], it's observed that water absorption in concrete mix increased when brick dust waste was used as a partial substitute for cement from between 5 and $30 \%$. Fluidity in the mix composition generally reduced under the same $\mathrm{w} / \mathrm{c}$ for varying mix compositions of brick dust waste, leading to higher stiffness and subsequent reduction in slump. In [15] it's shown that BDW has $25 \%$ more fineness compared to cement, and therefore requires a high amount of water during hydration when ground waste clay is used as a partial replacement. The gradual increase in percentages of BDW between $10 \%$ and $30 \%$ in fresh concrete influenced the ' $S$ ' value in their study. ' $S$ ' value is the mean value of the four sides distance from the edge top of the steel container to the surface of the compacted concrete. It thus follows that the lower the slump the higher the ' $S$ ' value and vice versa. Clear factors

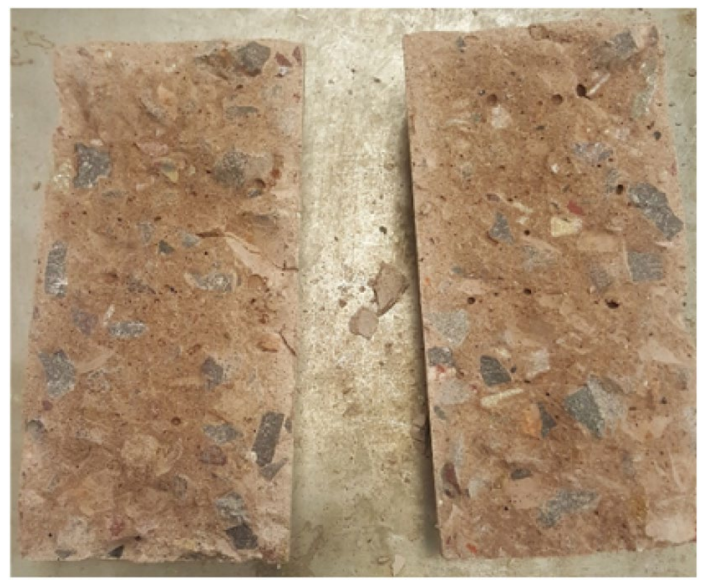

Fig. 14 Failed cylindrical specimen affecting compaction index include $\mathrm{w} / \mathrm{c}$, cement content, mix proportions, aggregate shape and size. All compaction index values achieved in the current study are within the target range as shown in Fig. 14 with the highest compaction index of $1.18 \mathrm{~mm}$ recorded for MC 1 .

\subsection{Hardened concrete}

\subsubsection{Unconfined compressive strength (UCS)}

A high compressive strength was achieved at later stages for all mix compositions in the current study. It's observed that at the early age of curing, a low compressive strength was generally observed but was followed by a predominate increase in compressive strength for all mix composition after curing age 7,14 and 28 days as shown in Fig. 15. But in a similar study conducted by [4] at different replacement of $5 \%, 10 \%$ and $15 \%$, a higher compressive strength was obtained with $15 \%$ brick dust waste. Another study by [16] revealed that a high compressive strength could be achieved when sand is replaced with up to $15 \%$ of BDW. Hardened concrete with BDW generally shows lower compressive strength at early ages, but a comparable strength with cement only concrete at later ages [12]. In the current study, MC 1 achieved the set target with a compressive strength of $36 \mathrm{~N} / \mathrm{mm}^{2}$, while desirable strength values of about $75 \%$ and $65 \%$ of the control strength were achieved with MC 2, MC 3 composed of $30 \%$ less cement did not achieve the desired compressive strength at even at 28 days. The results showed an increase in strength as curing age increases as the formation of calcium silicate hydrate gel (C-S-H) developed during the hydration process shown in Fig. 16. The presence of pozzolans reacts with the calcium hydroxide during hydration and forms calcium silicate hydrate gel (C-S-H) [17]. The pozzolanic characteristics are responsible for high
Fig. 15 Slump values of concrete mix with BDW

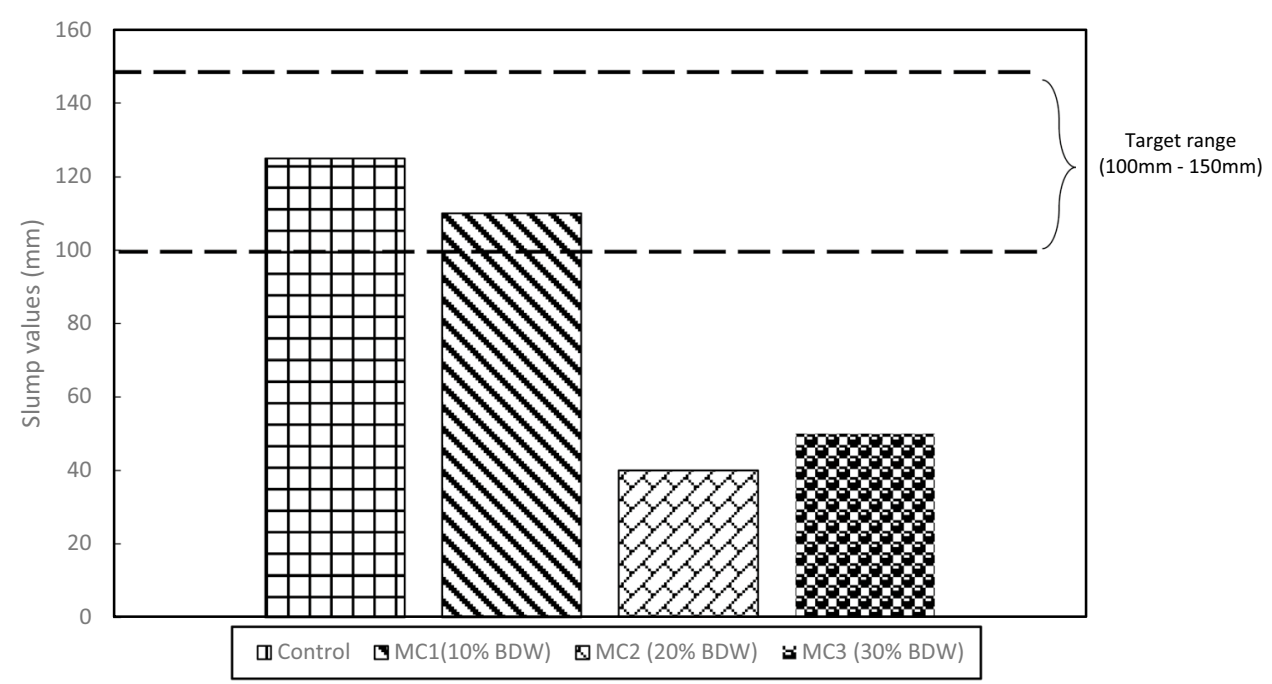


Fig. 16 Compaction index of concrete mix with BDW

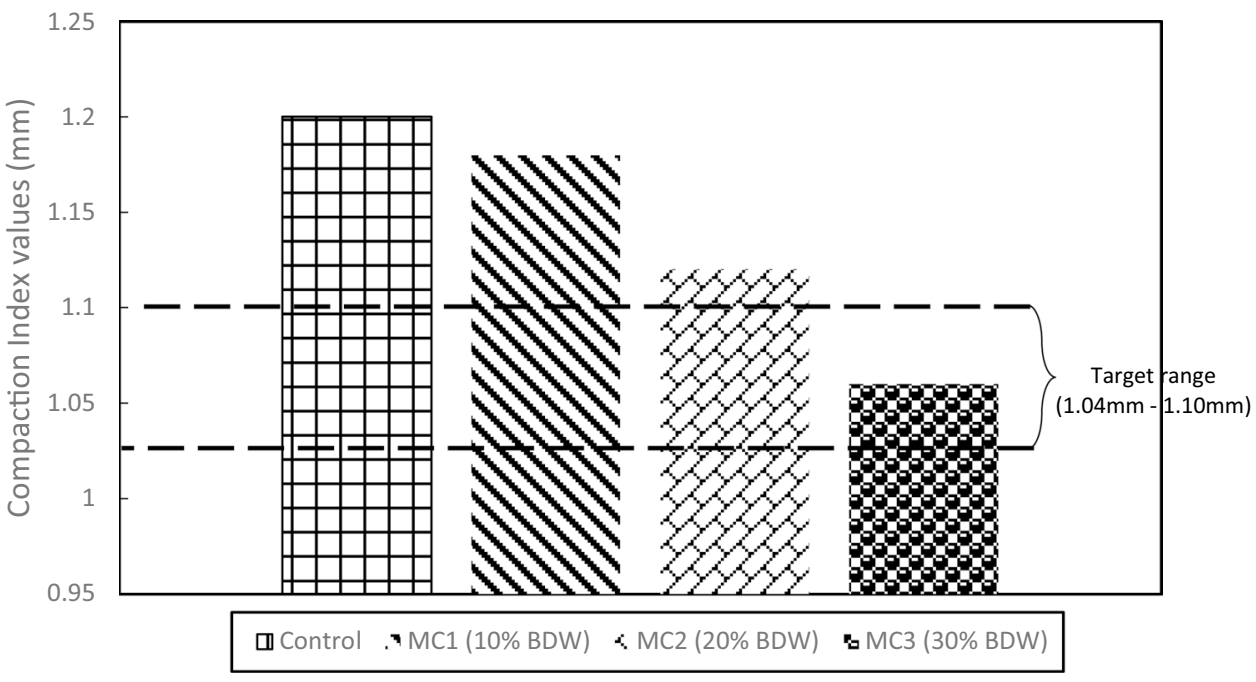

compressive strength at $50 \%$ brick waste replacement ratio [5]. The chemical reaction of brick dust in concrete shows a reaction of pozzolana with lime in the presence of water to form hydraulic compounds. The pozzolanic behaviour of ground clay brick (GCB) is similar to conventional materials such as fly ash and calcined clay at later age of 28 days [17]. The continuous of $\mathrm{C}-\mathrm{S}-\mathrm{H}$ gel within a pore structure contribute to strength development in concrete [14]. Results achieved in recent study show an increase in compressive strength as curing age increased due to the formation of $\mathrm{C}-\mathrm{S}-\mathrm{H}$ gel [18]. In line with this current study; development of additional $\mathrm{C}-\mathrm{S}-\mathrm{H}$ gel was observed when clay brick waste was used in mortar and concrete in an experimental study [19]. The high strength recorded for MC 1 can be attributed to the presence of pozzolanic material (brick waste) which contribute to high strength at a later age due to the rapid increase in silicon dioxide $\left(\mathrm{SiO}_{2}\right)$ leading to dicalcium silicate $(2 \mathrm{~S})$ which is responsible for high strength at later age. This is because
MC 1 has a lower cement replacement level which has resulted in high strength. Cement is responsible for the early strength of concrete and pozzolana from brick dust waste is responsible for strength at later ages by providing an extra amount of C-S-H gel [4]. Figure 17 shows the compressive test result. 3

\subsubsection{Tensile splitting strength (TSS) test}

MC 1 which is composed of $10 \%$ BDW achieved the highest TSS of $3.6 \mathrm{~N} / \mathrm{mm}^{2}$ in Fig. 18 compared to MC 2 and MC 3. The results show no significant difference in tensile strength for all mix compositions. However, a gradual reduction in strength as BDW percentage increase was observed for MC 2 and MC 3. High tensile strength was recorded when cement was replaced with $15 \%$ brick dust [4]. The close interval in tensile strength between mix compositions indicates a significant contribution to the increase in strength with the addition of BDW as a
Fig. 17 Compressive strength of concrete mix with BDW

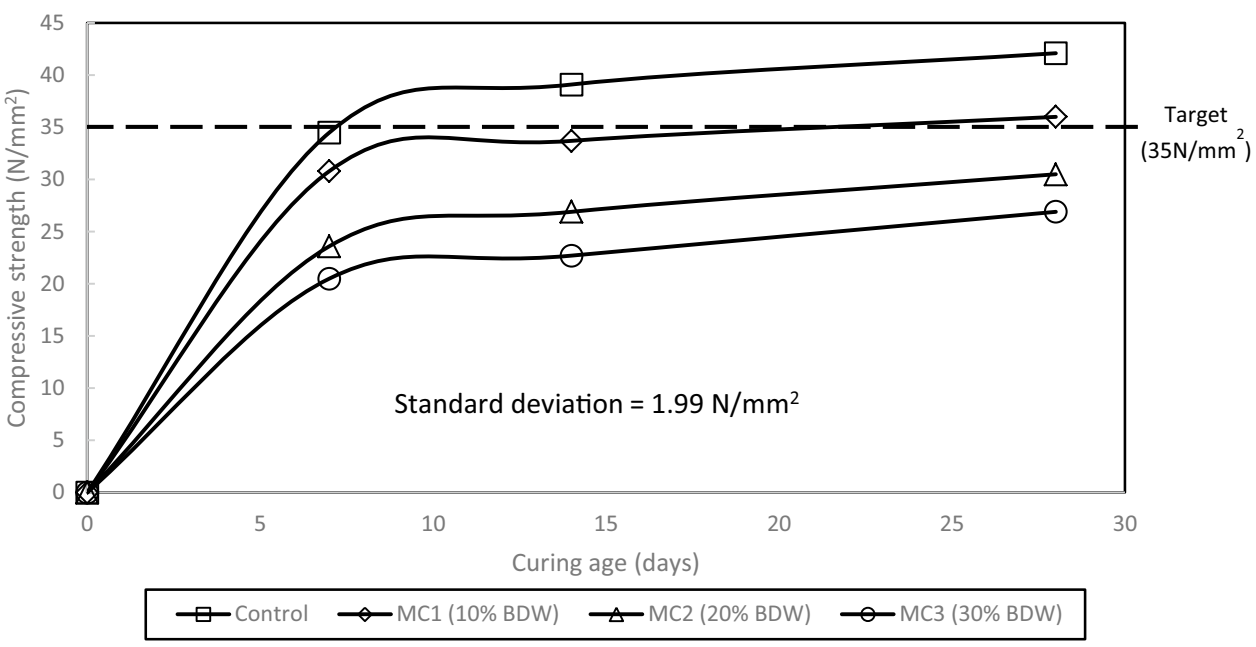


Fig. 18 Tensile strength of concrete mix with BDW

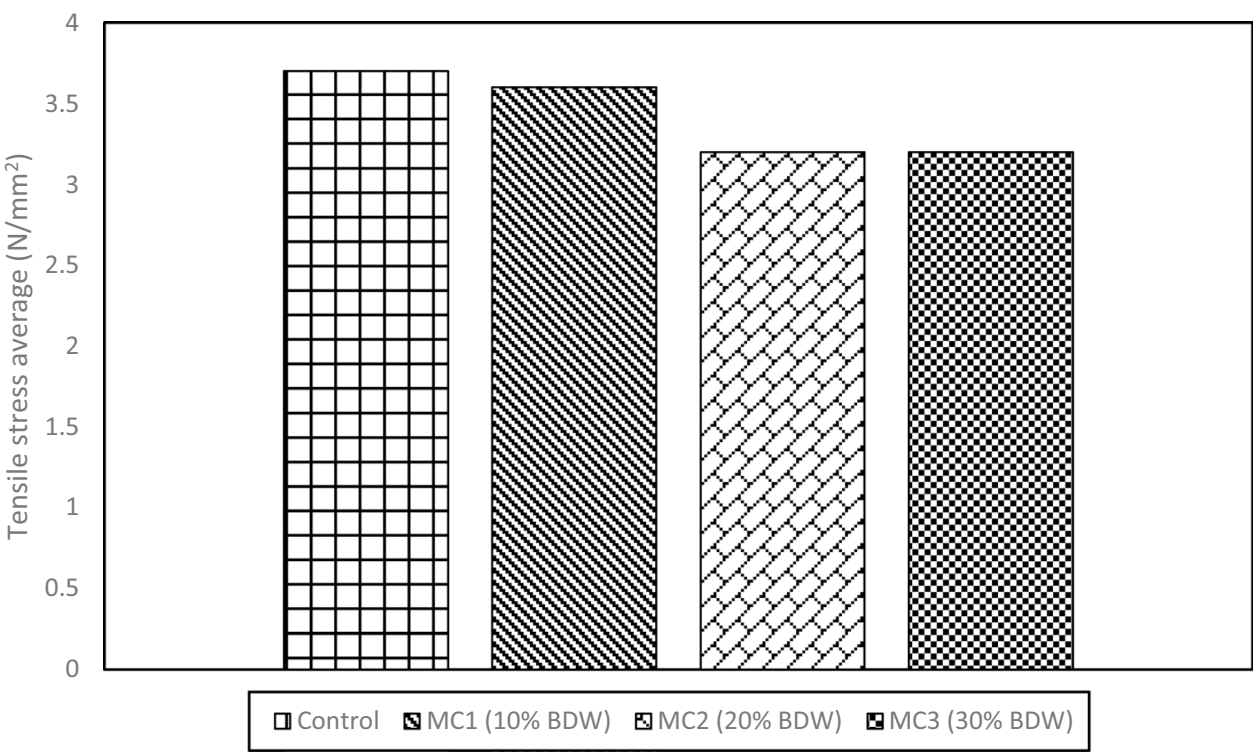

partial replacement for cement. The high tensile strength observed could be attributed to the angular shape of the aggregate coupled with the presents of pozzolans from BDW responsible for the production of high $\mathrm{C}-\mathrm{S}-\mathrm{H}$ gel during hydration [19]. Properties like tensile strength were significantly enhanced when waste materials were used to replace cement [4]. According to [17] tensile strength increased when brick waste was added to a concrete mix. The slow early strength observed in TSS is due to the presents of brick dust, however, the strength gain is higher compared to traditional concrete mix [17].

\section{Conclusion and recommendation}

The consistency and mechanical behaviour of concrete with varying proportions of brick dust waste content was investigated, discussed and the results showed high strength and good workability for all mix composition. MC 1 composed of $10 \%$ BDW achieved the highest UCS and TSS after 28 days of curing. MC 1 achieved all targets set in accordance with the relevant standard. A reduction in strength was observed with an increase in BDW percentage, However, the strengths achieved in this study are usable in construction. The strength pattern of concrete with $\mathrm{BDW}$ is similar to conventional concrete with cement only. A drastic reduction in slump was observed in MC 2 . However, the concrete is still usable for construction. Results showed that brick dust waste has high water absorption abilities which can lead to variation in slump compared to traditional concrete. An increase in strength with increase in curing age was observed for all mix compositions. Some limitations associated with using brick dust waste in concrete mix is the process of harvesting. Brick dust waste are mostly contaminated with various construction and demolition materials such as concrete, steel and wood, this makes it difficult to and time-consuming during separation. Grinding bricks into powder using heavy crushing machine generate lots of noise, dust, heat and carbon dioxide $\left(\mathrm{CO}_{2}\right)$ which affects the environment. However, this is low compared to the problems associated with cement production. After careful consideration on the results, it's recommended that at least $10 \%$ of cement can be replaced with BDW in concrete mix in real-life construction, in order to reduce overall construction cost. Future investigation into the effect of BDW on the durability and rheological properties of fresh concrete and steel reinforcement in concrete can be carried out.

\section{Declaration}

Conflict of interest The authors declare that they have no conflict of interest associated with this publication and no financial support has been given to influence the outcome of this work.

Open Access This article is licensed under a Creative Commons Attribution 4.0 International License, which permits use, sharing, adaptation, distribution and reproduction in any medium or format, as long as you give appropriate credit to the original author(s) and the source, provide a link to the Creative Commons licence, and indicate if changes were made. The images or other third party material in this article are included in the article's Creative Commons licence, unless indicated otherwise in a credit line to the material. If material is not included in the article's Creative Commons licence and your intended use is not permitted by statutory regulation or exceeds the permitted use, you will need to obtain permission directly from the copyright holder. To view a copy of this licence, visit http://creativecommons .org/licenses/by/4.0\%. 


\section{References}

1. European Environmental state and outlook, 2020. [online]. https ://www.eea.europa.eu/publications/soer-2020. Accessed: $21 \mathrm{Jul}$ 2020

2. Portland Cement Association, 2020. [online]. https://www. cement.org/economics/forecasts. Accessed: 21 Jul 2020

3. Word cement. [online]. https://www.worldcement.com/speci al-reports/15012020/2020-vision/. Accessed: 21 Jul 2020

4. Muhammed NA, Nabeel L, Ibrar A, Abdul B, Muhammad U, Muhammad AK (2018) Effect of brick dust on strength and workability of concrete. IOP Conf Ser Mater Sci Eng 414:012005. https ://doi.org/10.1088/1757-899X/414/1/012005

5. Ali AA, Abde. M, Esraa MA. (2014) Re-use of waste marble dust in the production of cement and concrete, constr. Build Mater. https://doi.org/10.1016/j.conbuildmat.2013.09.005

6. Alaa S, Sivakumar N, Kamal NM (2013) Properties of bricks made using fly ash, quarry dust and billet scale. Constr Build Mater. https://doi.org/10.1016/j.conbuildmat.2012.11.077

7. Praveenkumar S, Sankarasubramanian G (2019) Mechanical and durability properties of bagasse ash-blended high-performance concrete. Sci, SN Appl. https://doi.org/10.1007/s4245 2-019-1711-x

8. O'Farrell M, Wild S, Sabir B (2001) Cement composites-pore size distribution and compressive strength of waste clay brick mor$\operatorname{tar}$ 23(1):82. https://doi.org/10.1016/S0958-9465(00)00070-6

9. Muhammad BS, Abdullah A, Muhammad AT, Muhammad $Y$ (2013) Performance of pozzolanic concrete using different mineral admixtures. Pak J Eng Appl Sci 12:73-81

10. Walker R and Pavia S: (2011) Physical properties of pozzolans and their influence on the properties of lime-pozzolan paste, materials and structural, [online]. http://hdl.handle.net/2262/58454. Accessed: 16 Jul 2020

11. Spence RJS, Cook DJ (1983) Building materials in developing countries. Wiley, London

12. Viviana FR, Mónica AT, Alejandra T, Cloudia CC, Milena $P$, Jaroslav P, Edgardo FI, Ondřej J, Zbyšek P (2019) Complex characterisation and behaviour of waste fired brick powderPortland cement system. Materials. https://doi.org/10.3390/ ma12101650

13. Golaszewski J (1999) The influence of ground brick on the physical properties of mortar and concrete. In: Proceedings, Modern Concrete Materials: Binders, Additions and admixtures, Dundee, Thomas Telford, London, pp 119-130.

14. Sharda S, Ritesh M, Khalid R (2014) Effect of waste brick kiln dust with partial replacement of cement with adding superplasticizer in construction of paver blocks. Int J Sci Eng Technol Res 3(9):2261-2266

15. Kartini K, Rohaidah M, N, and Zuraini Z. A. (2012) Performance of ground clay bricks as partial cement replacement in grade 30 concrete. Int Scholarly Sci Res Innov 6(8):312-315

16. Rajesh KB, Patel RD (2014) A study on low performance concrete using mineral admixtures (brick kiln dust and silica fume). Int J Sci Res Dev 2(10):217-221

17. Faith (2007): Use of ground clay brick as a supplementary cementitious material in concrete hydration characteristics, mechanical properties, and ASR durability. PhD thesis. lowa state University. [online]. https://lib.dr.iastate.edu/cgi/viewc ontent.cgi? referer $=\&$ httpsredir $=1 \&$ article $=1091 \&$ context $=$ rtd. Accessed: 20 Jul 2020.

18. Yassin NIM, Adnan SH, Shahidan S, Ayop SS, Kamarulzaman NA, Osman MH, Jamelloddin Z, Majid M, Salleh N, Alisibramulisi A, Wehee AMNA (2020) Effects of curing conditions on properties of lightweight concrete brick containing expanded polystyrene and palm oil fuel ash. IOP Conf Ser: Mater Sci Eng 713:012006

19. Lihua Z, Zengmie Z (2020) Reuse of clay brick waste in mortar and concrete. Hindawi. Adv Mater Sci Eng. 2020, Article ID 6326178, pp 7, 5. https://doi.org/https://doi. org/10.1155/2020/6326178.

Publisher's Note Springer Nature remains neutral with regard to jurisdictional claims in published maps and institutional affiliations. 